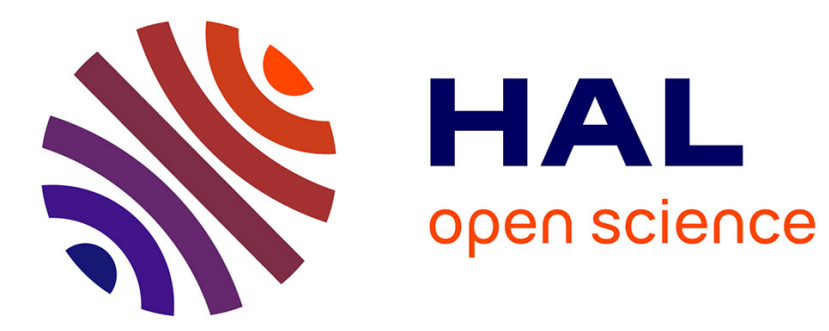

\title{
Pedogenetic Trends in Soils Formed in Technogenic Parent Materials
}

\author{
Hermine Huot, Marie-Odile Simonnot, Jean-Louis Morel
}

\section{To cite this version:}

Hermine Huot, Marie-Odile Simonnot, Jean-Louis Morel. Pedogenetic Trends in Soils Formed in Technogenic Parent Materials. Soil Science, 2015, 180 (4/5), pp.182-192. 10.1097/SS.0000000000000135 . hal-01594174

\section{HAL Id: hal-01594174 https://hal.science/hal-01594174}

Submitted on 26 Sep 2017

HAL is a multi-disciplinary open access archive for the deposit and dissemination of scientific research documents, whether they are published or not. The documents may come from teaching and research institutions in France or abroad, or from public or private research centers.
L'archive ouverte pluridisciplinaire HAL, est destinée au dépôt et à la diffusion de documents scientifiques de niveau recherche, publiés ou non, émanant des établissements d'enseignement et de recherche français ou étrangers, des laboratoires publics ou privés. 


\section{Pedogenetic Trends in Soils formed in Technogenic Materials}

ARTICLE in SOIL SCIENCE · DECEMBER 2015

Impact Factor: 0.79

READS

55

3 AUTHORS:

\section{Hermine Huot}

City University of New York - Brooklyn College 10 PUBLICATIONS 48 CITATIONS

SEE PROFILE

\section{Marie-Odile Simonnot}

University of Lorraine

106 PUBLICATIONS 1,109 CITATIONS

SEE PROFILE
Jean-Louis Morel

University of Lorraine - INRA

309 PUBLICATIONS $\quad \mathbf{5 , 7 7 0}$ CITATIONS

SEE PROFILE 


\title{
Pedogenetic trends in soils formed in technogenic parent materials
}

\author{
Hermine Huot $^{\text {a,b,c,d,1, }}$, Marie-Odile Simonnot ${ }^{\text {,dd }}$, Jean Louis Morel ${ }^{\text {a,b }}$
}

${ }^{a}$ Université de Lorraine, Laboratoire Sols et Environnement, UMR 1120, 2, avenue de la Forêt de Haye, TSA 40602, 54518 Vandoeuvre-lès-Nancy cedex, France

${ }^{\mathrm{b}}$ INRA, Laboratoire Sols et Environnement, UMR 1120, 2 avenue de la Forêt de Haye, TSA 40602, 54518 Vandoeuvre-lès-Nancy cedex, France

${ }^{c}$ Université de Lorraine, Laboratoire Réactions et Génie des Procédés, UMR 7274, 1 rue Granville, 54001 Nancy cedex, France

${ }^{\mathrm{d}}$ CNRS, Laboratoire Réactions et Génie des Procédés, UMR 7274, 1 rue Granville, 54001 Nancy cedex, France

Corresponding author:

Jean Louis Morel

Jean-Louis.Morel@univ-lorraine.fr

Mobile: +33607090229

Fax: +33383595991

Running title: Pedogenetic trends in Technosols

Sources of support that require acknowledgment:

This work was conducted within the framework of the French Scientific Interest Group on Industrial Wasteland (GISFI) program (www.gisfi.fr) and supported by the Région Lorraine, Institut Carnot Energie Environnement Lorraine (ICEEL), and ArcelorMittal Real Estate France (AMREF).

\footnotetext{
${ }^{1}$ Present address: Environmental Sciences Analytical Center - Brooklyn College of City University of New York, 2900 Bedford Avenue, Brooklyn, NY 11210, United States of America
} 


\begin{abstract}
Soils formed in technogenic parent materials are proliferating and their pedogenesis remains inadequately understood. Upon investigation of soils formed in various technogenic materials reported in the literature and of a Technosol developing on iron industry deposits, potential specificities of pedogenesis within technogenic materials are discussed. Analyses have shown that pedogenetic processes observed in these soils are similar to those occurring in natural soils. However, some particularities have been highlighted, such as the coexistence of processes rarely encountered simultaneously in natural environments or high rates of soil development during the first stages of weathering. Technogenic materials display highly diverse constituents, wide spatial variability, and temporal discontinuities as a result of human activities. These inherent features, in interaction with other soil-forming factors, may govern the pedogenesis by generating the following conditions: i) a high diversity of pedogenetic processes, including processes occurring usually in dissimilar climatic regions, ii) localized processes and distinct rates and orientations of soil development over short distance and iii) a succession and/or a superimposition of processes, constrained by the deposition of materials and human operations. This creates the potential for the simultaneity of processes coexisting rarely in natural soils developing in the same climatic region. These soils are likely to have a polycylic evolution and to evolve towards groups of soils other than Technosols, depending on the dominant processes. Further investigations of the processes and their potential interactions occurring in a larger range of soils formed in technogenic materials are required to better predict the evolution of these soils.
\end{abstract}

Key words: technogenic materials, pedogenesis, particular combination of processes, spatial heterogeneity, temporal discontinuities 


\section{Introduction}

By generating technogenic parent materials and changing conditions of pedogenesis, humans have become a major soil-forming factor (De Kimpe and Morel, 2000; Richter, 2007). Human-influenced soils are continually developing throughout the world in a wide range of areas, i.e., SUITMAs (Soils of Urban, Industrial, Traffic, Mining and Military Areas: Morel et al., 2015). Knowledge of the evolution and environmental consequences of these soils are of great importance, as they support a large variety of services (Morel et al., 2015) and they are more likely to be polluted (Rossiter, 2007).

Since 2006, the World Reference Base for Soil Resources takes into account a specific reference soil group, Technosols, which are soils containing more than $20 \%$ artefacts (i.e., materials created or modified by industrial or artisanal activities or brought to the surface by human activities), having a geomembrane or are being sealed (IUSS Working group WRB, 2014). In 2014, the latest edition of the Soil Taxonomy was amended to improve the morphologic description and the classification of soils formed in human-altered and humantransported materials, as recommended by the International Committee for the Classification of Anthropogenic Soils (ICOMANTH) (Galbraith, 2012).

Technogenic materials (artefacts) are diverse in relation to anthropogenic processes and include rubble and refuse of human settlement (e.g., bricks, concrete, plaster, plastic, glass, slag, coal, wood, garbage), industrial waste, mine spoil, dredged sediments, excavated bedrock or oil products. These materials may exist alone or may be mixed together, depending on the evolution and the variety of human activities (e.g., cultural layer in Moscow: Alexandrovskaya and Alexandrovskiy, 2000). In a context of increasing urbanization and the needs for mineral resources and energy, areas covered by technogenic materials extend every year on the Earth's surface (e.g., mine spoil: Hayes et al., 2014; Sokolov et al., 2015).

The deposition of technogenic materials results mainly from the storage or dumping of products without value. Also, some soils formed in technogenic materials are specifically designed for soil restoration and are based on soil engineering (e.g., constructed Technosols, green roof soils, soils for urban trees). In this case, the materials and the structuration in horizons are chosen to enable the soil to fulfill specific functions (Séré et al., 2008) or amendments are introduced intentionally to improve soil conditions and allow plant installation and growth (e.g., Zanuzzi et al., 2009).

Soils formed in technogenic materials are often characterized by a high spatial heterogeneity. They can be confined (e.g., settling ponds: Néel et al., 2003, Huot et al., 2014a; infiltration basins: Badin et al., 2009; dredged sediment landfills: Vandecasteele et al., 2009) or disseminated as patches in urban areas, in relation to the spread and distribution of the population, the development of the city or the design of transportation networks (Schleuss et al., 1998; Pouyat et al., 2010).

Technogenic materials can be deposited during one-time events (e.g., spill: Martin et al., 2007 or soil construction: Séré et al., 2010) or during cumulative events over time (e.g., successive dumping of industrial effluents: Néel et al., 2003; Huot et al., 2014a or successive inputs of technogenic materials as a result of human activities in urban areas: Prokof'eva and Poputnikov, 2010). Materials may be subjected to disturbances after deposition (e.g., excavation, mixing). 
Like natural bedrock, technogenic parent materials, more or less diverse and heterogeneous, evolve under the influence of other soil-forming factors (climate, organisms, and topography) over time.

The influence of parent materials in soil genesis is important, especially during the early stages. In general, soil inherits minerals from the parent materials, which are subjected to weathering over time and the subsequent formation of new minerals (Olson, 2005). The nature of the constituents, particle-size, and porosity of parent materials strongly determine the kinetics of weathering and control soil formation by accelerating or slowing chemical reactions (Duchaufour, 1995). Since technogenic materials are generally of artificial origin, they present a wide range of constituents and properties (e.g., pH, granulometry, porosity, specific surface area, etc.), and may display extreme values of these characteristics (Morel et al., 2005).

The specificity of technogenic parent materials may dictate the presence of peculiar pedogenetic processes.

\section{Objectives}

The objective of this paper is to discuss the specificities of pedogenesis in technogenic materials. The discussion to follow is based on investigations of soils formed in different types of technogenic materials (e.g., construction debris, mine spoil, industrial sludge and ashes, excavated bedrock, stormwater sediments) reported in the literature and from the example of a Technosol developing on a former iron industry settling pond (blast furnace sludge) under forest cover and a temperate climate since ca. $60 \mathrm{y}$, previously studied (Huot et al., 2013a, 2013b, 2014a, 2014b, 2015; Lucisine et al., 2015; Cortet et al., submitted).

First, pedogenetic processes described in this range of soils were reviewed and particularities were compared to those occurring in natural soils. Second, the potential for technogenic parent materials to govern pedogenesis was discussed in order to draw theoretical pedogenetic trends in these soils and hypotheses regarding their potential evolution.

\section{Comparison of pedogenetic processes in soils formed in technogenic materials with those occurring in natural soils}

Despite their young age, soils formed in various technogenic materials in industrial, mining and urban areas are subjected to pedogenetic processes under the influence of climatic conditions and the development of biological communities (Table 1). Analogies with pedogenesis of natural soils have been suggested but some specificities related to the technogenic origin of parent materials have also been highlighted. 
Table 1 Examples of pedogenetic processes observed in different types of Technosols depending on the nature of technogenic parent materials and other soil-forming factors

\begin{tabular}{|c|c|c|c|c|c|}
\hline parent materials & climate & organisms & age & observed processes & reference \\
\hline \multicolumn{6}{|c|}{ Technogenic materials deposited in urban areas } \\
\hline $\begin{array}{l}\text { demolition debris mixed } \\
\text { with soil, lacustrine sand } \\
\text { and clayey till }\end{array}$ & $\begin{array}{l}\text { humid-temperate } \\
\text { (mesic) (Detroit, } \\
\text { USA) }\end{array}$ & grass & 3 to $92 \mathrm{y}$ & $\begin{array}{l}\text { - A horizon development } \\
\text { - mortar weathering (dissolution/precipitation) } \\
\text { - slight decarbonation in A horizons and development } \\
\text { of calcic horizons } \\
\text { - nail weathering (oxido-reduction cycles) }\end{array}$ & Howard et al., 2013 \\
\hline 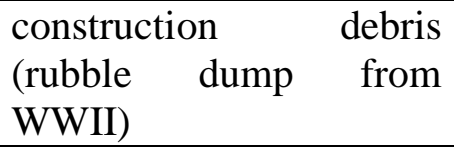 & $\begin{array}{l}\text { maritime } \\
\text { temperate (Berlin, } \\
\text { Germany) }\end{array}$ & & $40 \mathrm{y}$ & - release of sulfate & Abel et al., 2014 \\
\hline \multicolumn{6}{|c|}{ Materials related to industrial and mining activities } \\
\hline $\begin{array}{l}\text { lignite ash (landfills, } \\
\text { settling ponds, eolian } \\
\text { contamination) }\end{array}$ & $\begin{array}{l}\text { temperate } \\
\text { (Germany) }\end{array}$ & & $\begin{array}{l}5 \text { to } 32 \text { y } \\
\text { after } \\
\text { disposal } \\
\text { stop }\end{array}$ & $\begin{array}{l}\text { - OM accumulation at the surface } \\
\text { - downward movement of gypsum } \\
\text { - slight decarbonation } \\
\text { - glass weathering }\end{array}$ & Zikeli et al., 2002 \\
\hline $\begin{array}{lrr}\text { tailing } & \text { sumps of } & \text { coal } \\
\text { quarries } & \text { (dumps } & \text { of } \\
\text { sedimentary rocks) } & \end{array}$ & $\begin{array}{l}\text { sequence of } \\
\text { climates (Siberia): } \\
\text { humid - subhumid } \\
\text { - semiarid - arid - } \\
\text { extracontinental } \\
\text { arid }\end{array}$ & $\begin{array}{l}\text { taiga } \\
\text { steppe } \\
\text { dry steppe }\end{array}$ & $\begin{array}{l}3 \text { groups: } \\
-\quad \text { young } \\
\text { soils }(<10 \\
\text { y) } \\
-\quad \text { medium } \\
\text { age (10-20 } \\
\text { y) } \\
\text { - old soils } \\
(>20 \mathrm{y})\end{array}$ & $\begin{array}{l}\text { - profile development leading by i) disintegration of } \\
\text { stony fragments and profile differentiation by their } \\
\text { content, then ii) OM transformation and formation of } \\
\text { organic horizons } \\
\text { - some aggregates observed in humus-cumulative } \\
\text { horizons of old dump soil formed in subhumid climate } \\
\text { - formation of iron-manganic concretions } \\
\text { - mummification of OM in arid and semiarid soils }\end{array}$ & Sokolov et al., 2015 \\
\hline $\begin{array}{l}\text { sulfide-rich mine tailings } \\
\text { (gold mine) }\end{array}$ & $\begin{array}{l}\text { temperate } \\
\text { (France) }\end{array}$ & $\begin{array}{l}\text { uncovered (near } \\
\text { pipe) grass - }\end{array}$ & $\begin{array}{lr}35 \text { y } & \text { since } \\
\text { stop } & \text { of }\end{array}$ & $\begin{array}{l}\text { - humus addition } \\
\text { - sulfide oxidation }\end{array}$ & Néel et al., 2003 \\
\hline
\end{tabular}




\begin{tabular}{|c|c|c|c|c|c|}
\hline & & $\begin{array}{l}\text { trees } \\
\text { (boundaries) }\end{array}$ & deposits & $\begin{array}{l}\text { - leaching of products of sulfide oxidation } \\
\text { - clay translocation at the microscopic scale }\end{array}$ & \\
\hline $\begin{array}{l}\text { sulfide-ore derived mine } \\
\text { tailings }\end{array}$ & $\begin{array}{l}\text { semi-arid } \\
\text { (Arizona, US) }\end{array}$ & & $\begin{array}{l}50 \text { y since } \\
\text { deposition }\end{array}$ & $\begin{array}{l}\text { progressive oxidative weathering front (gossan zone): } \\
\text { - dramatic change in color } \\
\text { - decrease in } \mathrm{pH} \\
\text { - change in mineralogy (near complete depletion of } \\
\text { sulfides in surface and formation of secondary } \\
\text { minerals as a function of depth) }\end{array}$ & Hayes et al., 2014 \\
\hline $\begin{array}{l}\text { alkaline slurry produced } \\
\text { by soda industry }\end{array}$ & $\begin{array}{l}\text { semi-humid } \\
\text { (Germany) }\end{array}$ & $\begin{array}{l}\text { natural } \\
\text { succession } \\
\text { vegetation }\end{array}$ & $\begin{array}{l}\text { time series: } \\
15,19, \quad 57 \\
\text { and } 70 \text { year- } \\
\text { deposits }\end{array}$ & $\begin{array}{l}\text { - carbonation (dominating process during the first } \\
60 \mathrm{y} \text { )/decarbonation (in the topsoil after } 60 \mathrm{y} \text { ) } \\
\text { - enrichment in organic } \mathrm{C} \text { at the surface } \\
\text { - development of fine granular structure at the surface } \\
\text { - leaching of soluble salts (mainly } \mathrm{NaCl} \text { ) } \\
\text { - formation and alteration of minerals influenced by } \\
\text { changes in pH }\end{array}$ & Grünewald et al., 2007 \\
\hline $\begin{array}{l}\text { fly ash-capped bauxite } \\
\text { residues }\end{array}$ & $\begin{array}{l}\text { tropical monsoon } \\
\text { (Brazil) }\end{array}$ & $\begin{array}{l}\text { tree/shrub cover } \\
\text { with understorey } \\
\text { cover (seedlings } \\
\text { planted in 1996) }\end{array}$ & $\begin{array}{l}15 \text { y since } \\
\text { establishme } \\
\text { nt of } 50-\mathrm{cm} \\
\text { thick fly ash } \\
\text { cap and } \\
\text { seedlings }\end{array}$ & $\begin{array}{l}\text { - leaching of soluble salts and formation of } \\
\text { epihyposodic or endosodic horizons in depth } \\
\text { - structuration: formation of blocky peds in bauxite } \\
\text { residues (desiccation cracks) and weak granular root- } \\
\text { bound aggregates within the upper } 10 \mathrm{~cm} \text { of the fly } \\
\text { ash } \\
\text { - OM accumulation and N enrichment at the surface } \\
\text { - formation of cambic horizon (depletion incarbonates } \\
\text { and structure development) }\end{array}$ & Santini and Fey, 2015 \\
\hline \multicolumn{6}{|c|}{ Excavated bedrocks and sediments } \\
\hline $\begin{array}{l}\text { excavated Callovo- } \\
\text { Oxfordian clay material }\end{array}$ & $\begin{array}{l}\text { temperate } \quad(\mathrm{NE} \\
\text { France })\end{array}$ & $\begin{array}{l}\text { spontaneous } \\
\text { vegetation (low } \\
\text { growth) }\end{array}$ & $10 \mathrm{y}$ & $\begin{array}{l}\text { - leaching of soluble compounds (sulfate, carbonate) } \\
\text { - oxidation of primary sulfides and Fe minerals, } \\
\text { loss of montmorillonite } \\
\text { - precipitation of gypsum and secondary minerals } \\
\text { (e.g., kaolinite) } \\
\text { - OM enrichment at the surface }\end{array}$ & Scholtus et al., 2014 \\
\hline
\end{tabular}




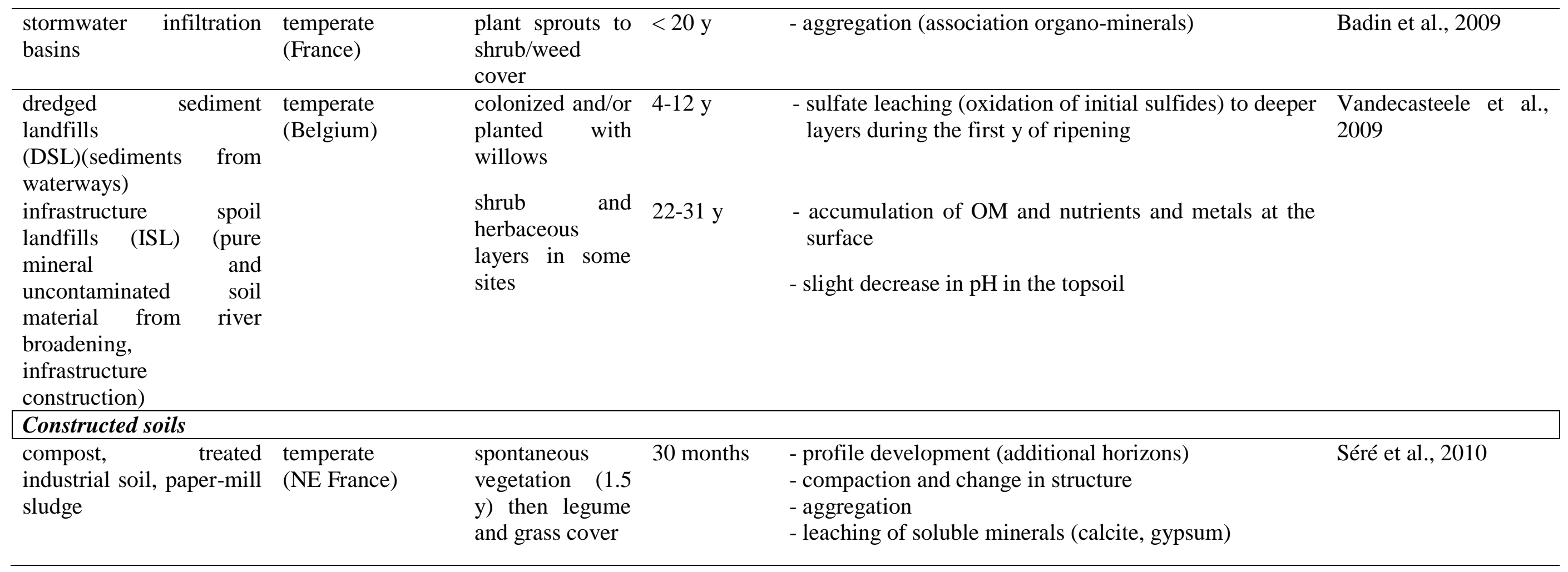




\section{Similar processes of soil formation from technogenic and natural materials}

The first group of processes reported refers to the biogeochemical weathering of technogenic materials under the influence of climatic conditions and then of organisms.

Leaching of soluble compounds (e.g., chlorides, sulfates, carbonates) driven by rainfall has often been documented in the first stages of weathering (e.g., Zikeli et al., 2002; Séré et al., 2010; Abel et al., 2014; Scholtus et al., 2009, 2014; Huot et al., 2015; Santini and Fey, 2015). Mineral transformations are important indicators of the evolution of technogenic materials under environmental factors. The oxidation of sulfides, the formation of secondary minerals (sulfates, $\mathrm{Fe}$ (hydr)oxides) and sulfate leaching are reported in sulfide-bearing materials when exposed to oxidizing conditions in contact with the atmosphere (e.g., sulfide-rich mine tailings: Néel et al., 2003; Uzarowicz and Skiba, 2011; Uzarowicz, 2013; Hayes et al., 2014; excavated bedrock: Scholtus et al., 2014; dredged sediments: Vandecasteele et al., 2009). Changes in redox conditions related to wetting/drying cycles also contribute to the formation of Fe-Mn concretions and/or coatings (e.g., Huot et al., 2014a; Sokolov et al., 2015) as well as the weathering of iron artefacts (e.g., nails: Howard et al., 2013, 2015). Carbonation, by reaction with atmospheric and microbial $\mathrm{CO}_{2}$, may occur during the early stages of weathering of alkaline materials (e.g., Grünewald et al., 2007). The weathering of glass in poorly crystalline aluminosilicates has been reported in soils formed in fly ash (e.g., Zevenbergen et al., 1999; Zikeli et al., 2002) and in iron industry by-products (e.g., Sauer and Burgardt, 2006; Huot et al., 2014a).

Other important processes in the first steps of development of soils formed in technogenic materials are organic matter $(\mathrm{OM})$ accumulation and humification at the surface (Bini and Gaballo, 2006). These processes have often been described in various vegetated technogenic materials, such as mine tailings (e.g., Schafer et al., 1980; Néel et al., 2003, Bini and Gaballo, 2006; Uzarowicz and Skiba, 2011), industrial by-products (Zikeli et al., 2002; Grünewald et al., 2007; Huot et al., 2014b), construction debris (Howard et al., 2013), excavated bedrock (Scholtus et al., 2014) and dredged sediments (Vandecasteele et al., 2009). Accumulation depends on the nature and the density of vegetation cover, on the ability of materials to host plants (Néel et al., 2003), and on the climate (Sokolov et al., 2015). The input of exogenous mineral and organic matter (e.g., atmospheric dust, bird excrements, human wastes) may also drive urban soil development (Charzyński et al., 2014).

Processes of aggregation involving inorganic and organic technogenic materials have also been reported (e.g., Badin et al., 2009; Monsérié et al., 2009; Séré et al., 2010). The structure in technogenic materials generally shows weak development. But blocky peds due to desiccation cracks and granular structure in topsoil due to root activity have been observed in industrial by-products (e.g., Grünewald et al., 2007; Santini and Fey, 2015).

With time, a slight decarbonation of the topsoil may occur in calcareous materials (e.g. Zikeli et al., 2002; Grünewald et al., 2007). As a result of leaching, soluble compounds can precipitate in deeper layers (e.g., secondary calcite in cracks: Huot et al., 2014a) and lead to the formation of calcic (e.g., Howard et al., 2013), gypsic (e.g., Zikeli et al., 2002, 2005) or sodic (e.g., Santini and Fey, 2015) horizons.

All of these processes contribute to relatively rapid differentiation of horizons during the early stages of pedogenesis (Martín et al., 2007; Séré et al., 2010). Most soils present an A-C profile with increasing thickness of the organo-mineral horizon with age (e.g., Bini and Gaballo, 2006; Grünewald et al., 2007). Subsequently the profile may evolve towards an A-B- 
C type with the development of a cambic horizon due to changes in structure and migration of carbonates (e.g., Bini and Gaballo, 2006) and/or accumulation of salts.

According to the reported examples (Table 1), pedogenetic processes described in soils formed in technogenic materials are comparable to those leading to the formation of natural soils. Analogies with natural soils have been suggested based on soil properties and/or diagnostic horizons. For example, soils formed on building roofs, walls or rain gutters may be considered as analogues of weakly developed soils (Rendzic Leptosols, Folic Histosols, ornithogenic soils) (Charzyński et al., 2014). The strong stratification of some industrial deposits may be compared to fluvic materials (Zikeli et al., 2005). Similarly, the upward growth of urban soil profiles by regular inputs of anthropogenic materials has been compared to the profile development of natural alluvial soils (Prokof'eva and Poputnikov, 2010). Soils derived from lignite ashes and blast furnace sludge meet most of the criteria for andic properties (Zikeli et al., 2005; Huot et al., 2013a). Similarities between the weathering of volcanic ashes and coal fly ash or by-products from iron industry have been highlighted (Zevenbergen et al. 1999; Sauer and Burghardt, 2006).

\section{Pedogenetic specificities reported in soils formed in technogenic materials}

However, differences between Technosol and natural soil pedogenesis have also been described. For instance, the weathering of technogenic mineral phases may lead to the formation of minerals not often observed in natural soils (Grünewald et al., 2007) or the formation of minerals with different compositions from those found in natural soils (e.g., lower $\mathrm{Al} / \mathrm{Si}$ ratio in aluminosilicates formed in fly ash or blast furnace sludge due to the alkaline conditions) (Zevenbergen et al., 1999; Zikeli et al., 2005; Huot et al., 2013a). While lignite ash-derived soils show properties similar to natural volcanic soils, some characteristics (e.g., carbonates, sulfates, high $\mathrm{pH}$, high organic carbon content) inherent to the technogenic materials are rarely encountered in natural volcanic soils in similar climatic regions (Zikeli et al., 2005). Similarly, the investigated Technosol formed in blast furnace sludge displays i) redoximorphic features resulting from the former dissolution, transport and precipitation of Mn oxides as in hydromorphic soils with a fluctuating water table (Figure 1.c, d and e), ii) tracks of weathering of industrial glass-like phases and the formation of poorly crystalline aluminosilicates comparable to the alteration of volcanic ashes resulting in the formation of allophanes, and iii) migration of carbonates and precipitation of secondary carbonates, which are common processes in carbonated soils (Figure 1.f and g) (Huot et al., 2014a; 2015). These processes rarely coexist in natural soils and lead to the development of distinct groups of soils (e.g., hydromorphic, volcanic, carbonated soils).

Pedogenetic processes have also been reported as more intense and rapid in some technogenic materials than in natural materials (e.g., Zevenbergen et al., 1999; Grünewald et al., 2007; Rossiter, 2007; Séré et al., 2010; Howard et al., 2013). As a result, some soils formed in technogenic materials show an unusually high rate of development, at least in the first stages of weathering. However, the rate and the orientation may be variable over a short distance due to the high diversity and spatial heterogeneity of technogenic materials (Néel et al., 2003). 

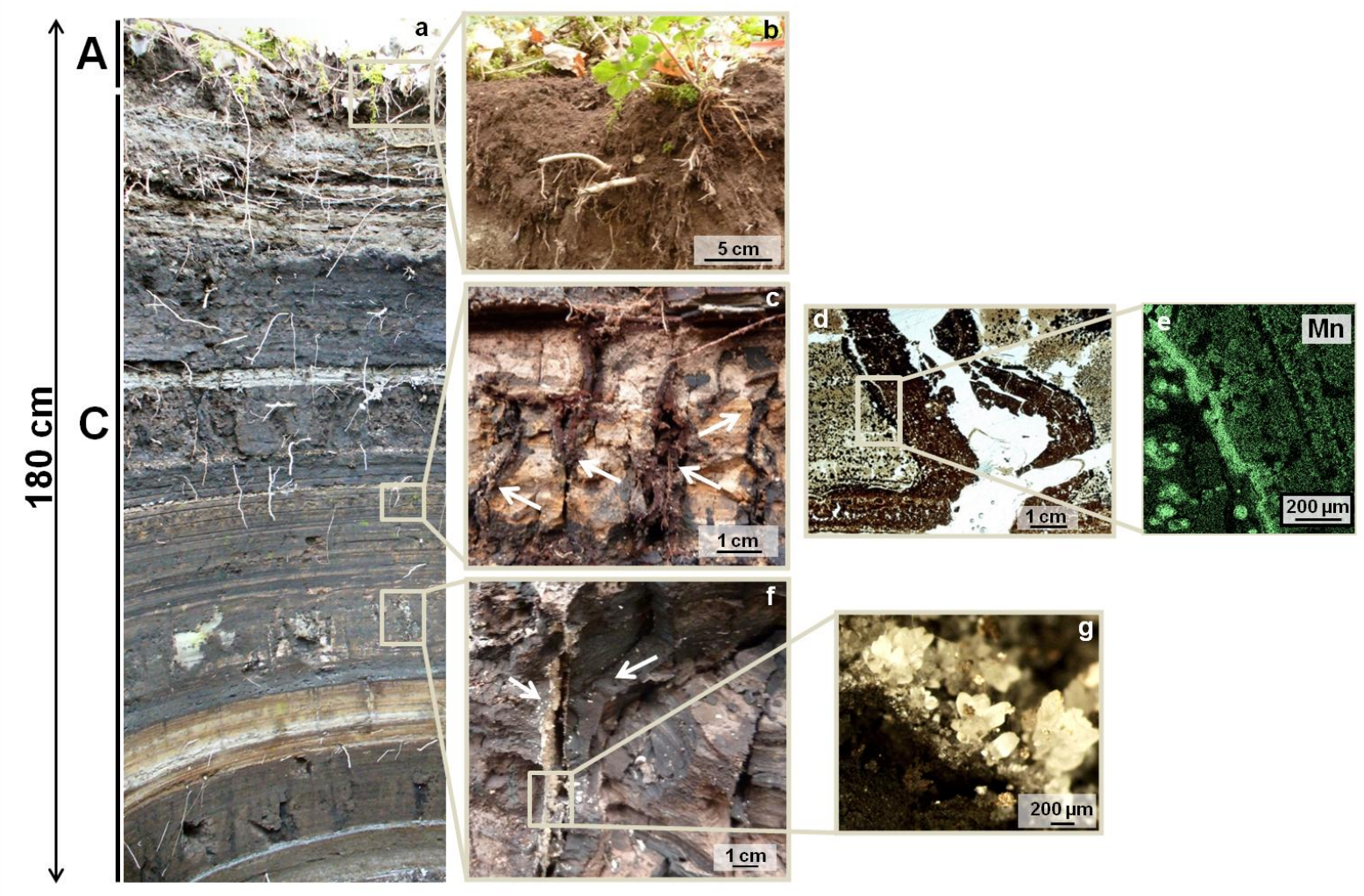

Figure 1 Technosol profile developing on a former iron industry settling pond showing succession of processes in preferential areas

(a) view of the $\mathrm{A} / \mathrm{C}$ profile with details of the organo-mineral horizon (b) and of cracks with dark Mn-rich coatings (c, d, e), sometimes covered by whitish calcitic coatings (f, g) and colonized by roots (c). Mn-rich coatings were observed using a stereomicroscope on thin sections (d) and analyzed by SEM-EDS (e). Redrawn after Huot et al., 2014a.

\section{Potential for technogenic parent materials to govern pedogenesis}

As a result of human activities, technogenic materials are likely to display a high diversity of constituents, a high spatial variability and a range of temporal discontinuities. The potential for technogenic parent materials to govern pedogenesis is discussed in the following subsections based on the interactions of these features with other soil-forming factors (climate, organisms, topography, time) and is summarized in Table 2.

\section{Diversity and nature of technogenic constituents as a result of anthropogenic processes}

Anthropogenic processes generate a high diversity of technogenic materials, that could result in soil parent material composition quite distinct from that of natural bedrock or sediments. For instance, blast furnace sludge resulting from the ferromanganese production process contains Mn-bearing minerals, carbonates and silicate glass-like phases, which coexist rarely in natural bedrock (Huot et al., 2014a). This enables particular combinations and interactions to occur between processes related to the weathering of the technogenic constituents and the varying influence of climate and organisms. The nature of technogenic materials may also govern pedogenesis by constraining the development of organisms and influencing the rates of weathering. 


\section{a) Weathering of technogenic materials as a result of climatic conditions}

As in natural soils, climate influences the rate of development of soils formed in technogenic materials as well as their weathering trajectories. For example, in arid environments, development of organic horizons in soils formed in coal quarry tailing dumps is less pronounced (Sokolov et al., 2015). Similarly, the oxidative front in sulfide-rich mine tailings progresses more slowly. Low water flux limits sulfate leaching, which inhibits the transformation of metastable minerals (Hayes et al., 2014).

However, the original mixture of technogenic constituents and related physico-chemical conditions could favor processes which might usually take place in different climatic regions when occurring in natural soils (Séré, 2007). For instance, in temperate humid regions, anthropogenic gypsum from construction debris or industrial by-products is leached (e.g., Zikeli et al., 2002; Séré et al., 2010; Abel et al., 2014; Huot et al., 2015). This may lead to the accumulation of secondary gypsum in deeper layers, which is usually encountered in dry climatic conditions (Zikeli et al., 2005). Similarly, OM mummification, a typical process in cryoarid soils, is also observed in soils developed on tailing dumps of coal quarries under less arid conditions (Sokolov et al., 2015).

\section{b) Technogenic materials as driver of organism development}

As in natural soils, organisms are drivers of the development of soils formed in technogenic materials, through the accumulation and decomposition of organic matter at the surface (e.g., Bini and Gaballo, 2006), the pedoturbation and the formation of organo-mineral associations (e.g., burrowing activity of earthworms: Pey et al. 2013; Howard et al., 2015) or the rhizosphere effect (e.g., Huot et al., 2013b). Organisms also contribute to changing the conditions for the weathering of technogenic materials. For example, plants and microorganisms may release organic acids favoring the dissolution of calcareous artefacts. Some bacteria are involved in changes in redox potential driving the weathering of ferruginous artefacts (Howard et al., 2013). Carbonation and decrease in $\mathrm{pH}$ in alkaline substrates is partly driven by microbial respiration (Grünewald et al., 2007). Earthworm activity can modify the context of artefacts in urban soils by burying the materials at greater depth or by improving the diffusion of water and air through their vertical burrows, thereby promoting artefact weathering (Howard et al., 2015).

However, the technogenic nature of the parent materials may strongly constrain the development of organisms. Materials derived from human activities may be phytotoxic or present unfavorable physical or chemical properties (e.g., lack of nutrients and available water, compaction, cementation, high $\mathrm{pH}$, high salt contents), thereby inhibiting the development of vegetation and soil organisms and associated soil-forming processes (e.g., OM accumulation) (Zikeli et al., 2002; Néel et al., 2003). In a context of remediation, a capping layer or soil amendments can be added to support plant growth and seedlings can be planted (e.g., bauxite residues covered by fly ash: Santini and Fey, 2015). By contrast, diversified ecosystems can develop naturally on technogenic materials but the structure of communities may differ from those observed in analogous ecosystems formed on natural parent materials. This in turn, may influence the pedogenetic processes driven by biological activity. For example, soil fauna composition in a forested ecosystem developed on a former settling pond of iron industry showed some particularities compared to the community composition in analogous alluvial forests of the region (e.g., high abundance of detritivores, low abundance of earthworms). This lack of endogeic species may contribute to the litter 
accumulation at the surface of this soil (Lucisine et al., 2015; Cortet et al., submitted) . Similarly, slow colonization by some species may also retard soil development, e.g., absence of earthworms limits the OM incorporation in the topsoil formed in dredged sediments (Vandeasteele et al., 2009). Eventually, changes driven by organisms may be limited due to restricted volumes of soil under the influence of these organisms (e.g., localized transformations of blast furnace sludge deposits within the rhizophere: Huot et al., 2013b).

\section{c) Rate of weathering of technogenic materials}

As in natural soils, the rate of weathering depends on the reactivity of parent materials and the environmental conditions. The degree of weatherability of technogenic materials depends on their nature (e.g., mineralogy, organic compounds) and characteristics (e.g., grain-size, porosity, specific surface area), resulting from anthropogenic processes.

The rapid and intense weathering frequently reported during the early pedogenesis of Technosols could be explained by the disequilibrium between technogenic materials and environmental conditions (Scholtus et al., 2009; Séré et al., 2010). For instance, substantial weathering may occur when materials are subjected to the transition from a reducing to an oxidizing environment at the surface (e.g., dredged sediments: Vandecasteele et al., 2009; excavated bedrock: Scholtus et al., 2009) or when materials containing soluble salts are subjected to rainfall-driven leaching (Grünewald et al., 2007; Séré et al., 2010; Scholtus et al., 2014; Santini and Fey, 2015). However, this rapid and intense weathering could be a specificity of incipient soils and the weathering rate may decrease with time (Séré et al., 2010), as observed in natural soils following a normal "top down" model of soil development (Alexandrovskiy, 2007).

In addition to this disequilibrium, anthropogenic making-processes (e.g., industrial or mining processes) may also favor mineral weathering by improving material reactivity (e.g., reduction of particle-size, low crystallinity) and by generating extreme physico-chemical conditions promoting material alteration (e.g., high or low $\mathrm{pH}$, high pressure, high temperature, high humidity). For example, ore crushing during the gold extraction process generates permeable materials allowing the migration of water and fine particles (Néel et al., 2003). Another example is the accelerated weathering of coal fly ash compared to the alteration of natural volcanic ash due to the high $\mathrm{pH}$ of fly ash promoting rapid dissolution of glasses (Zevenbergen et al., 1999). Human activities may also generate conditions promoting the weathering of technogenic materials. For instance, in urban and traffic areas, salts or sulfates resulting from deicing salts (Suaire et al., 2013), plaster, or sulfurous air pollutants may accelerate the weathering rate of cement and iron artefacts by corrosion (Howard and Olszewska, 2010).

However, anthropogenic processes also generate recalcitrant technogenic materials and conditions limiting weathering rates. For instance, urban soils may contain high amounts of weathering-stable artefacts (e.g., bricks: Nehls et al., 2013 or glass: Howard et al., 2015) or relatively recalcitrant forms of organic carbon due to human activities, Black Carbon (Nehls and Shaw, 2010; Howard et al., 2015). Moreover, fine and microporous technogenic materials (e.g., blast furnace sludge) may favor the retention of water and elements, the preservation of organic matter, and limit fluxes (Huot et al., 2014b, 2015). The formation of desiccation cracks during the drying of bauxite residues causes macropore flow, which promotes rapid leaching along the ped faces but limits the dissolution of phases present in the peds (Santini and Fey, 2015). Additionally, urban soils are likely to be compacted or to have compacted layers, limiting the infiltration of water and air as agents of weathering (Howard et al., 2015). 
Interactions between weathering processes of diverse artefacts may also influence the weathering rates of materials. For instance, leaching of phosphates from bones or carbonates from mortar and precipitation of a protective coating of carbonates or vivianite contribute to the preservation of iron artefacts (Howard et al., 2015).

Thus, the diversity, nature and mixture of technogenic materials in interaction with environmental factors make the simultaneous occurrence of diverse pedogenetic processes possible, and make these processes more or less intense and rapid.

\section{Spatial variability}

Human activities (e.g., deposition of industrial by-products in settling ponds, demolition, excavation, mixing) generate high lateral and vertical variability in technogenic parent materials. As a result, city soil surveys reveal high pedodiversity and strong soil spatial variability, depending on the history of the city (e.g., New York City: New York City Soil Survey Staff, 2005; Polish cities: Charzyński et al., 2013). At smaller scales, lateral variations in composition, grain-size, and porosity may be recorded in confined deposits of technogenic materials (e.g., settling ponds) and so may influence the soil development (Néel et al., 2003). Soil profiles are likely to display discontinuities in the parent material, such as strong stratification resulting from the successive dumping of a variety of materials depending on changes in mining or industrial processes (Figure 1.a) (e.g., Néel et al., 2003; Huot et al., 2014a,b). Local heterogeneities (e.g., textural change, compacted layers) may change the hydrodynamics of the soil and constrain the development of organisms. Cracks and interfaces between the layers may promote preferential areas of mixing and weathering processes (e.g., Huot et al., 2014a; Santini and Fey, 2015).

\section{a) Influence of changes in topography and hydrology induced by human activities}

Human activities (e.g., excavation, filling, building construction, wars) may also change the (micro)topography and consequently the local hydrology. These modifications may influence the pedogenetic rates as well as the nature of processes occurring in the soil after disturbance. For instance, the accumulation of technogenic materials coupled with a gradual leveling of the topography may cause a rise in the groundwater table, limiting OM decomposition as observed in the lower part of urban soils in Moscow (Alexandrovskaya and Alexandrovskiy, 2000). Another example is the effect of warfare ("bombturbation"), which induced changes in the meso- and microtopography and consequently the surface hydrology of the soil in a WWI battlefield (Verdun, France) (Hupy and Schaetzl, 2008). Craters became the focal points for runoff, litter, and sediments and hence became preferential areas of soil development unlike the hummocks, which shed water and litter. The formation of perched water tables in some locations generated the conditions for new pedogenetic processes (e.g., gleyzation) and slowed down soil development. Furthermore, stabilization of earthy materials by log crib walls in steep slopes enhances the speed of pedogenesis by counteracting the topography factor (Scalenghe and Ferraris, 2009).

\section{b) Spatial constraint for colonization by organisms}

Spatial heterogeneities may constrain the colonization of technogenic materials by organisms, which develop in preferential areas (e.g., roots in cracks and macropores: Huot et al., 2013b) with favorable conditions (e.g., higher $\mathrm{pH}$, more available water and nutrients, more organic matter, better structure). This may result in uneven vegetation coverage at the surface and 
heterogeneous distribution of soil organisms along profiles. Spatial heterogeneities may also explain the establishment of ecosystems on phytotoxic materials (e.g., Hüttl and Weber, 2001; Néel et al., 2003; Bini and Gaballo, 2006). These preferential areas are likely to be subjected to more rapid pedogenesis due to modifications driven by biological activity (e.g., Néel et al., 2003; Hupy and Schaetzl, 2008; Huot, 2013b).

Thus, spatial heterogeneities of technogenic materials make the occurrence of localized processes and/or different pedogenetic rates possible over short distances (e.g., Néel et al., 2003; Bini and Gaballo, 2006).

\section{Temporal discontinuity}

Formation of soils formed in technogenic parent materials is likely to be constrained by temporal discontinuities during the deposition of parent materials at the surface (e.g., successive inputs of materials) and by human interventions after deposition (e.g., excavation, mixing, demolition, amendments). For example, soils formed on building walls are often ephemeral, depending on the maintenance of the building and its demolition (Charzyński et al., 2014). Soils formed on dumping sites are continuously disturbed by new material additions, mixing, and compaction. As a result, soils developed on technogenic parent materials are likely to form in several steps as well as to display a polycylic evolution (e.g., superposition of mine spoil over native soil: Bini and Gaballo, 2006).

The nature, intensity, and duration of these soil-forming processes may be constrained by material reactivity, changes in interactions with environmental factors, as well as the time span occurring between successive of deposition events or disturbances. Similarly, floodplain soils are also characterized by the uneveness in the rates of pedogenetic processes and the degree of development of these soils depends on the rate of sediment accumulation (Alexandrovkiy, 2007). For example, the input of amendments may accelerate soil development by improving chemical and physical properties of inhospitable materials, thereby favoring the colonization by organisms, as drivers of soil formation (e.g., mine spoil: Zanuzzi et al., 2009).

Materials disposed of discontinuously are subjected to two stages of alteration: surface and subsurface weathering. After burial by a new layer of materials, subsurface weathering occurs similarly to soils formed in successive deposits of volcanic ash (Wada, 1987). The processes occurring during the first phase of alteration may be slowed down or even stopped when the new layer of materials limits the direct effects of climatic and biological activity. As a result, tracks of earlier weathering can be "fossilized." For instance, mineral changes and solute transfer at the interface between layers of blast furnace sludge are evidence of the changes in redox conditions between successive deposits (Huot et al., 2014a). Another example is the formation of thin organic layers in the urban soil of Moscow. These soils developed under herbaceous vegetation and trees when the duration of interruption between material deposits was sufficient (>10-20 y) (Alexandrovskaya and Alexandrovskiy, 2000). Thus, urban soils display both an anthropogenic "book-like memory" typical of sediments, in which properties acquired at the surface are stored in buried horizons, and the erasing type of soil memory ("palimpsest memory") typical of the development of natural soils (Prokofov'eva and Poputnikov, 2010).

Successive inputs of technogenic materials or human transformations raise the question of the onset of pedogenesis. Alteration between successive deposits could be considered as the parent material formation, on which soil will develop later. However, weathering of technogenic materials due to environmental factors (e.g., desiccation, oxidation/reduction, 
leaching) contributes to pedogenesis by modifying physico-chemical properties of the parent materials and by creating preferential areas of soil development (e.g., desiccation cracks). These discontinuities allow the succession of processes to occur at different time scales. For instance, some cracks in blast furnace sludge are coated by manganese oxide (dissolution/precipitation in the early alteration phase) then secondary calcite (leaching and precipitation of carbonates) and are colonized by roots (rhizospheric processes) (Figure 1.f; Huot et al., 2013b).

Thus, the temporal discontinuities in deposition of technogenic parent materials may create conditions for the succession and simultaneity of processes existing at different time scales. 
Table 2 Potential for technogenic parent materials to govern the pedogenesis of Technosols, based on the interactions of inherent features of technogenic materials (high diversity of constituents, high spatial variability, temporal discontinuities) with other soil-forming factors (climate, organisms, topography, time)

\begin{tabular}{|c|c|c|c|c|}
\hline $\begin{array}{c}\text { technogenic } \\
\text { parent materials }\end{array}$ & climate & organisms & topography & time \\
\hline \multicolumn{4}{|c|}{$\begin{array}{l}\text { technogenic materials may be in disequilibrium } \\
\text { with environmental conditions }\end{array}$} & $\begin{array}{l}\text { possible intense and rapid } \\
\text { first stage of weathering }\end{array}$ \\
\hline \multirow{2}{*}{$\begin{array}{l}\text { diversity of materials } \\
\quad \text { (mixture })\end{array}$} & $\begin{array}{l}\text { possible occurrence of } \\
\text { processes usually found } \\
\text { under dissimilar climates }\end{array}$ & $\begin{array}{l}\text { toxicity or unfavorable } \\
\text { conditions of some } \\
\text { materials may constrain the } \\
\text { development of organisms }\end{array}$ & & $\begin{array}{l}\text { anthropogenic processes influence } \\
\text { the degree of weatherability } \\
\text { and the conditions of weathering } \\
\text { of the technogenic materials }\end{array}$ \\
\hline & $\begin{array}{l}\text { diversity of processes } 1 \\
\text { technogenic materials } u\end{array}$ & $\begin{array}{l}\text { ated to the weathering of } \\
\text { der environmental factors }\end{array}$ & & $\begin{array}{l}\text { weathering of some artefacts may } \\
\text { enhance the preservation of others }\end{array}$ \\
\hline spatial variability & & $\begin{array}{l}\text { may promote preferential } \\
\text { areas of development of } \\
\text { organisms }\end{array}$ & $\begin{array}{l}\text { possible local changes } \\
\text { in hydrodynamics }\end{array}$ & $\begin{array}{c}\text { possible distinct rates of soil } \\
\text { development over short distances }\end{array}$ \\
\hline $\begin{array}{c}\text { temporal } \\
\text { discontinuity }\end{array}$ & & $\begin{array}{c}\text { amendments favor } \\
\text { biological activity and } \\
\text { associated pedogenetic } \\
\text { processes }\end{array}$ & & $\begin{array}{l}\text { succession of processes } \\
\text { ("fossilized" processes) and/or } \\
\text { simultaneity of processes } \\
\text { occurring at different time scales }\end{array}$ \\
\hline
\end{tabular}




\section{Pedogenetic trends and scenarios of evolution for soils formed in technogenic parent materials}

From the review of pedogenetic processes described in a range of soils formed in technogenic materials and the discussion of the potential specificities of the weathering of these parent materials compared to the pedogenesis on natural materials, some theoretical pedogenetic trends of soils formed in technogenic materials and hypotheses regarding their potential evolution may be drawn (Figure 2).

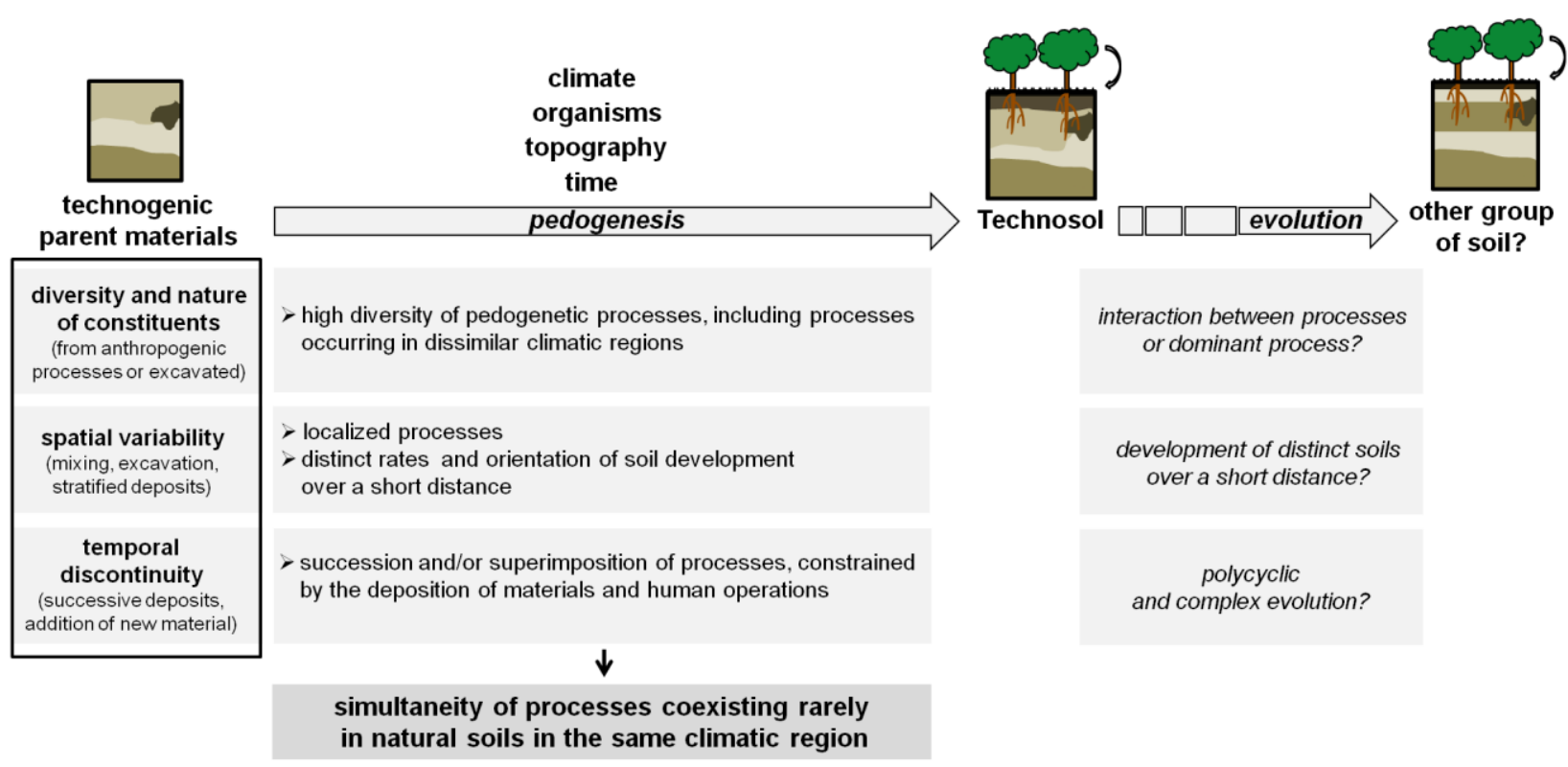

Figure 2 Potential specificities of the pedogenesis of soils formed in technogenic materials and their evolution

\section{Pedogenetic trends in soils formed in technogenic materials}

The characteristics of the technogenic materials in interaction with other soil-forming processes may generate the following conditions: i) a high diversity and mixture of constituents, a high diversity of pedogenetic processes, and the potential for processes usually occurring in dissimilar climatic conditions to be present; ii) a high spatial variability of technogenic materials and changes in topography resulting from human activities, localized processes and/or distinct rates of soil development over short distances; and iii) successive and simultaneous processes existing at different time scales, constrained by the deposition of technogenic materials and other operations due to human activities.

All these interactions create the possibility for processes rarely coexisting in natural soils developing in the same climatic conditions to be present simultaneously. This may be specific to pedogenesis of soils formed in technogenic materials, at least during the early stages of their evolution. The occurrence of peculiar combinations of processes remains to be investigated in a larger range of soils formed in technogenic materials.

\section{Evolution scenarios of soils formed in technogenic materials}

In the World Reference Base for Soil Resources, Technosols are defined by the nature of their parent materials. The influence of technogenic materials on pedogenesis tends to decrease with time, as weathering contributes to their transformation and degradation. Consequently, Technosols tend to evolve towards other soil groups. Attempts to predict the long-term 
evolution of Technosols formed in excavated bedrock have been made from the investigation of mature natural soils formed in similar materials (Scholtus et al., 2014). Other examples of such predictive comparison have been developed through analogy with natural soils and soilforming processes occurring in the climatic regions (e.g., Cambisol: Séré et al., 2010; Andosol, Ferralsol: Santini and Fey, 2015; podzolisation, gleying: Sokolov et al., 2015).

However, the evolutionary rate and extent of these young soils could be influenced by the interactions of pedogenetic processes, as well as by spatial and temporal variability dictated by the technogenic nature of the parent materials.

\section{a) Interaction of processes}

When contrasting processes operate simultaneously, multiple pedogenetic orientations are considered. With time, one process may become predominant. Its prevalence may occur more or less rapidly depending on the nature of technogenic materials. Such processes will lean to the formation of a soil belonging to a group that would develop naturally in the same climatic region. However, interactions between contrasting processes should be taken into consideration. For instance, if process A (e.g., carbonation/decarbonation) changes the properties controlling process $\mathrm{B}$ (e.g., $\mathrm{pH}$ ), the extent, rate and outputs of process $\mathrm{B}$ could be modified (e.g., accelerated dissolution of industrial glass-like phases under high $\mathrm{pH}$ giving rise to aluminosilicates with different composition from volcanic soils: Zevenbergen et al., 1999). Consequently, the orientation of pedogenesis and the usual sequence of processes observed in natural soils may be distinct in Technosol formation.

\section{b) Spatial scale}

The evolution of a Technosol may be different over a short distance, as a result of the spatial variation between the set of soil-forming factors (i.e., parent material, microtopography, organisms). Layers of materials of contrasting nature in stratified technogenic parent materials are subjected to distinct weathering trajectories leading to distinct soils. For example, capped bauxite residues under tropical climate may evolve towards a Ferralsol while a fly ash cap may evolve towards an Andosol (Santini and Fey, 2015). Technogenic parent materials may also display lateral variability, which is likely to create the conditions for the development of distinct soils over short distances. For instance, a sulfide-rich mine tailing may give rise to a fertile mine soil free of $\mathrm{Fe}$ oxides and sulfates at the boundaries of the pond. However, materials in the vicinity of the waste discharge may evolve towards an acidic sulfate soil with a horizon of accumulation of oxides or sulfates (Néel et al., 2003).

\section{c) Time scale}

Technosols are likely to have polycyclic or complex evolutions due to successive deposits of materials or disturbances changing the orientation of pedogenesis and the record of earlier processes in buried materials. Evolution of new deposits may be divided into different steps in which distinct processes occur with varying intensity. During an initial stage, reactive technogenic materials in disequilibrium with the environment are often subjected to intense changes (e.g., leaching of soluble compounds, oxidation of minerals) (e.g., Séré et al., 2010; Scholtus et al., 2014; Huot et al., 2014a). The onset of colonization by organisms starts a new phase, characterized by the occurrence of processes driven by biological activity (e.g., OM accumulation) (e.g., Néel et al., 2003; Huot et al., 2014a).

The orientation of pedogenesis and the time needed for the Technosol to evolve to another soil group depends on the nature and proportion of technogenic materials as well as the given 
environmental factors (climate, organisms, topography). The addition of new technogenic materials may prolong the classification of the soil as Technosol.

\section{Conclusion}

The degree to which specific pedogenetic processes characterize the evolution of soils formed in technogenic materials has been investigated. Here, we demonstrate that soils formed in different technogenic materials (e.g., construction debris, mine spoil, industrial waste, excavated bedrock) do not reveal specific pedogenetic processes compared to pedogenesis on natural parent materials. However, the diversity of technogenic materials may result in unique mixtures of constituents and present high spatial and temporal variability. Such diverse parent materials create the potential for the simultaneity of pedogenetic processes that would rarely coexist in natural soils forming in the same climatic region. With time, the influence of technogenic materials on pedogenesis will decrease and a Technosol will evolve towards another group of soil, depending on the dominant processes. A "technic" qualifier would indicate the origin of parent material.

The prediction of the evolution of these young human-influenced soils requires further investigation of these peculiar combinations of processes and their potential interactions in a larger range of technogenic materials and of climatic conditions. Modeling of pedogenesis of these soils should be adapted to take into account the diversity of technogenic materials and the complex relations between weathering processes, which could change the orientation and the rate of pedogenesis. Space-scale should also be adjusted to fit potentially distinct soil development over short distances as well as the occurrence of localized processes, in relation to the usual high spatial variability of technogenic materials. Time-scale should be multiscalar in order to represent the likely polycyclic evolution in several steps with varying rates, depending on the reactivity of the technogenic materials to environmental factors, the time span between successive inputs of materials or disturbances as well as the burial of materials (Leguédois et al., 2016).

\section{Acknowledgments}

This work was conducted within the framework of the French Scientific Interest Group on Industrial Wasteland (GISFI) program (www.gisfi.fr) and supported by the Région Lorraine, Institut Carnot Energie Environnement Lorraine (ICEEL), and ArcelorMittal Real Estate France (AMREF).

The authors wish to thank the staffs of the Laboratoire Sols et Environnement, Laboratoire Réactions et Génie des Procédés, Laboratoire Interdisciplinaire des Environnements Continentaux, Géoressources, Laboratoire de Chimie Physique et Microbiologie pour l'Environnement and of the GISFI for their help in performing the analyses and interpreting the data. They would also like to thank Sophie Leguédois and Geoffroy Séré for the discussions about the pedogenesis of Technosols, as well as Sara Perl Egendorf for proofreading the manuscript as a native English speaker. They also thank the reviewers and editors for their helpful comments. 


\section{References}

Abel S., T. Nehls, B. Mekiffer, M. Mathes, J. Thieme, and G. Wessolek. 2014. Pools of sulfur in urban rubble soils. J. Soils Sediments 15(3):532-540.

Alexandrovskaya E.I., and A.L. Alexandrovskiy. 2000. History of the cultural layer in Moscow and accumulation of anthropogenic substances in it. Catena 41(1): 249-259.

Alexandrovskiy A.L. 2007. Rates of soil-forming processes in three main models of pedogenesis. Rev. mex. cienc. geol. 24(2): 283-92.

Badin, A.L., G. Méderel, B. Béchet, D. Borschneck, and C. Delolme. 2009. Study of the aggregation of the surface layer of Technosols from stormwater infiltration basins using grain size analyses with laser diffractometry. Geoderma 153(1): 163-171.

Bini C., and S. Gaballo. 2006. Pedogenetic trends in anthrosols developed in sulfidic mine spoils: A case study in the Temperino mine archaeological area (Campiglia Marittima, Tuscany, Italy). Quatern. int. 156:70-78.

Charzyński P., P. Hulisz, R.M. Bednarek, and P.T. Gleboznawcze. 2013. Technogenic soils of Poland. Polish Society of Soil Science.

Charzyński P., P. Hulisz, R.M. Bednarek, A. Piernik, M. Winkler, and M. Chmurzyński. 2014. Edifisols — a New Soil Unit of Technogenic Soils. J. Soils Sediments 15(8):1675-1686.

Cortet J., H. Huot, G. Echevarria, P. Marion, J.F. Masfaraud, L. Florentin, J.L. Morel, J. Muller, C. Otterman, J. Nahmani, S. Ouvrard, C. Pernin, C. Schwartz, C. Sirguey, and F. Watteau. Biodiversity and trace elements biogeochemical cycles in a highly contaminated forest Technosol. submitted to Chemosphere.

De Kimpe, C.R., and J.L. Morel. 2000. Urban soil management: a growing concern. Soil Sci. 165(1):31-40.

Duchaufour, P. 1995. Pédologie : sol, végétation, environnement. Abrégés, Masson, Paris.

Galbraith J.M. 2012. Rationale for proposed changes to soil taxonomy concerning the International Committee for Anthropogenic Soils. Soil Horiz. 53(2).

Grünewald G., K. Kaiser, and R. Jahn, 2007. Alteration of secondary minerals along a time series in young alkaline soils derived from carbonatic wastes of soda production. Catena 71(3): 487-96.

Hayes S.M., R.A. Root, N. Perdrial, R.M. Maier, and J. Chorover. 2014. Surficial weathering of iron sulfide mine tailings under semi-arid climate. Geochim. cosmochim. ac. 141: 240-57.

Howard J.L., and D. Olszewska. 2011. Pedogenesis, geochemical forms of heavy metals, and artifact weathering in an urban soil chronosequence, Detroit, Michigan. Environ. Pollut. 159:754-761. 
Howard J.L., B.R. Dubay, and W.L. Daniels. 2013. Artifact Weathering, Anthropogenic Microparticles and Lead Contamination in Urban Soils at Former Demolition Sites, Detroit, Michigan. Environ. Pollut. 179:1-12.

Howard J.L., K. Ryzewski, B.R. Dubay, and T.W. Killion. 2015. Artifact preservation and post-depositional site-formation processes in an urban setting: a geoarchaeological study of a 19th century neighborhood in Detroit, Michigan, USA. J. Archaeol. Sci. 53:178-89.

Huot H., M.O. Simonnot, P. Marion, J. Yvon, P. De Donato, and J.L. Morel. 2013a. Characteristics and Potential Pedogenetic Processes of a Technosol Developing on Iron Industry Deposits . J. Soils Sediments 13(3): 555-68.

Huot H.. 2013b. Formation, fonctionnement et évolution d'un Technosol sur des boues sidérurgiques. $\mathrm{PhD}$ dissertation. Université de Lorraine.

Huot H., M.O. Simonnot, F. Watteau, P. Marion, J. Yvon, P. De Donato, and J.L. Morel. 2014a. Early transformation and transfer processes in a Technosol developing on iron industry deposits. Eur. J. Soil Sci. 65:470-84.

Huot H., P. Faure, C. Biache, C. Lorgeoux, M.O. Simonnot, and J.L. Morel. 2014b. A Technosol as archives of organic matter related to past industrial activities. Sci Total Environ. 487:389-398.

Huot H., G. Séré, P. Charbonnier, M.O. Simonnot, and J.L. Morel. 2015. Lysimeter monitoring as assessment of the potential for revegetation to manage former iron industry settling ponds. Sci Total Environ. 256:29-40.

Hupy J.P., and R.J. Schaetzl. 2008. Soil development on the WWI battlefield of Verdun, France. Geoderma 145(1):37-49.

Hüttl R.F., and E. Weber. 2001. Forest ecosystem development in post-mining landscapes: a case study of the Lusatian lignite district. Naturwissenschaften 88(8):322-329.

IUSS Working Group WRB. 2014. World Reference Base for Soil Resources 2014.

International soil classification system for naming soils and creating legends for soil maps.World Soil Resources Reports No. 106. FAO, Rome.

Leguédois S., G. Séré, A. Auclerc, J. Cortet, H. Huot, S. Ouvrard, F. Watteau, C. Schwartz, and J.L. Morel. 2016. Modelling pedogenesis of Technosols. Geoderma 262:199-212.

Lucisine P., M. Danger, V. Felten, D. Aran, A. Auclerc, H. Huot, A. Lecerf, J.L. Morel, S. Muller, J. Nahmani, and F. Maunoury-Danger. 2015. Litter chemistry prevails over litter consumers in mediating effects of past steel industry activities on leaf litter decomposition, Sci. Total Environ. 537:213-224.

Martín F., M. Diez, I. García, M. Simón, C. Dorronsoro, A. Iriarte, and J. Aguilar. 2007. Weathering of Primary Minerals and Mobility of Major Elements in Soils Affected by an Accidental Spill of Pyrite Tailing. Sci. Total Environ. 378(1-2):49-52. 
Monsérié M.F., F.Watteau, G.Villemin, S. Ouvrard, and J.L. Morel. 2009. Technosol genesis: identification of organo-mineral associations in a young Technosol derived from coking plant waste materials. J. Soils Sediments 9(6): 537-546.

Morel J. L., C. Schwartz, L. Florentin, and C. De Kimpe. 2005. Urban soils. In: Encyclopedia of Soils in the Environment. Hillel D. (ed.). Academic Press, London, 2900 p.

Morel J.L., C. Chenu, and K. Lorenz. 2015. Ecosystem services provided by soils of urban, industrial, traffic, mining, and military areas (SUITMAs). J. Soils Sediments 15:1659-1666.

Néel C., H. Bril, A. Courtin-Nomade, and J.P.Dutreuil, 2003. Factors affecting natural development of soil on 35-year-old sulfide-rich mine tailings. Geoderma 111 (1):1-20.

Nehls T., and R.K. Shaw. 2010. Black carbon in soils: Relevance, analysis, distribution. Soil Survey Horizons 51:79-84.

Nehls T., S. Rokia, B. Mekiffer, C. Schwartz, and G. Wessolek. 2013. Contribution of Bricks to Urban Soil Properties. J. Soils Sediments 13(3): 575-84.

New York City Soil Survey Staff. 2005. New York City Reconnaissance Soil Survey. United States Department of Agriculture, Natural Resources Conservation Service, Staten Island, NY.

Olson K.R. 2005. Parent material as a soil forming factor. Encyclopedia of Soils and the Environment. Academic Press, Elsevier, 532-536.

Pey B., J. Cortet, F. Watteau, K. Cheynier, and C. Schwartz. 2013. Structure of earthworm burrows related to organic matter of a constructed Technosol. Geoderma 202:103-111.

Pouyat R., V. K. Szlavecz, I. D. Yesilonis, P. M. Groffman, and K. Schwarz. 2010. Chemical, physical, and biological characteristics of urban soils. In: AgronomyMonograph 55.Urban Ecosystem Ecology.Aitkenhead-Peterson J., and A. Volder (eds.). American Society of Agronomy, Crop Science Society of America, Soil Science Society of America, Madison, WI. p. 119-152.

Prokof'eva T.V., and V.O. Poputnikov. 2010. Anthropogenic transformation of soils in the Pokrovskoe-Streshnevo park (Moscow) and adjacent residential areas. Eurasian Soil Sci. 43(6):701-11.

Richter D.D. 2007. Humanity's transformation of Earth's soil: Pedology's new frontier. Soil Sci. 172(12):957-967.

Rossiter D. 2007. Classification of Urban and Industrial Soils in the World Reference Base for Soil Resources. J. Soils Sediments 7(2): 96-100.

Santini T.C., and M.F. Fey. 2015. Fly ash as a permeable cap for tailings management: pedogenesis in bauxite residue tailings. J. Soils Sediments 15(3): 552-64. 
Sauer D., and W. Burghardt. 2006. The occurrence and distribution of various forms of silica and zeolites in soils developed from wastes of iron production. Catena 65(3): 247-57.

Scalenghe R., and S. Ferraris. 2009. The First Forty Years of a Technosol. Pedosphere 19(1): 40-52.

Schafer W.M., G.A. Nielsen, and W.D. Nettleton. 1980. Minesoil genesis and morphology in a spoil chronosequence in Montana. Soil Sci. Soc. Am. J.44(4): 802-7.

Schleuss U., Q. Wu, and H.P. Blume. 1998. Variability of soils in urban and periurban areas in Northern Germany. Catena 33(3):255-270.

Scholtus N., G. Echevarria, L. Florentin, M.L. Bonis, P. De Donato, M.O. Simonnot, and J.L. Morel. 2014. Expected evolution of a Technosol derived from excavated Callovo-Oxfordian clay material. J. Soils Sediments 15(2):332-346.

Scholtus N., E. Leclerc, P. De Donato, J.L. Morel, and M.O. Simonnot. 2009. Eluto-frontal chromatography to simulate chemical weathering of COx by low-molecular-weight organic compounds and early pedogenesis processes. Eur. J. Soil Sci. 60(1):71-83.

Séré G. 2007. Fonctionnement et évolution pédogénétiques de Technosols issus d'un procédé de construction de sol. $\mathrm{PhD}$ dissertation, Institut national polytechnique de Lorraine.

Séré G., C. Schwartz, S. Ouvrard, C. Sauvage, J.C. Renat, and J.L. Morel. 2008. Soil Construction: A Step for Ecological Reclamation of Derelict Lands. J. Soils Sediments 8(2): 130-136.

Séré G., C. Schwartz, S. Ouvrard, J.C. Renat, F. Watteau, G. Villemin, and J.L. Morel. 2010. Early pedogenetic evolution of constructed Technosols. J. Soils Sediments 10 (7): 1246-54.

Sokolov D.A., V.A. Androkhanov, S.P. Kulizhskii, E.A. Domozhakova, and S.V. Loiko. 2015. Morphogenetic Diagnostics of Soil Formation on Tailing Dumps of Coal Quarries in Siberia. Eurasian Soil Sci. 48(1): 95-105.

Suaire R., I. Durickovic, M.O. Simonnot, and M. Marchetti. 2013. Monitoring of Road Deicers in a Retention Pond. Int. J. Measurement Technologies Instrumentation Engineering 3(1): 39-47.

Uzarowicz L., and S. Skiba. 2011. Technogenic soils developed on mine spoils containing iron sulfides: Mineral transformations as an indicator of pedogenesis. Geoderma 163(1):95108.

Uzarowicz L. 2013. Microscopic and microchemical study of iron sulphide weathering in a chronosequence of technogenic and natural soils. Geoderma 197-198:137-150.

Vandecasteele B., P. Quataert, G. Genouw, S. Lettens, F.M.G. Tack. 2009. Effects of willow stands on heavy metal concentrations and top soil properties of infrastructure spoil landfills and dredged sediment-derived sites. Sci. Total Environ. 407:5289-5297. 
Wada K. 1987. Minerals formed and mineral formation from volcanic ash by weathering.

Chem. Geol. 60(1-4):17-28

Zanuzzi A., J.M. Arocena, J.M. Van Mourik, and A. Faz Cano. 2009. Amendments with organic and industrial wastes stimulate soil formation in mine tailings as revealed by micromorphology. Geoderma 154(1):69-75.

Zevenbergen C., J.P. Bradley, L.P. Van Reeuwijk, A. Shyam, O. Khjelmar, and R.N.J. Comans. 1999. Clay formation and metal fixation during weathering of coal fly ash. Environ. Sci. Technol. 33(19): 3405-3409.

Zikeli S., R. Jahn, and M. Kastler, 2002. Initial soil development in lignite ash landfills and settling ponds in Saxony-Anhalt, Germany. J. Plant Nutr. Soil Sc. 165(4):530-536.

Zikeli, S., M. Kastler, and R. Jahn. 2005. Classification of anthrosols with vitric/andic properties derived from lignite ash. Geoderma 124(3-4):253-265 